\title{
Retirement and cognitive development in the Netherlands: Are the retired really inactive?
}

Citation for published version (APA):

de Grip, A., Dupuy, A., Jolles, J., \& van Boxtel, M. (2015). Retirement and cognitive development in the Netherlands: Are the retired really inactive? Economics \& Human Biology, 19, 157-169.

https://doi.org/10.1016/j.ehb.2015.08.004

Document status and date:

Published: 01/01/2015

DOI:

10.1016/j.ehb.2015.08.004

Document Version:

Publisher's PDF, also known as Version of record

Document license:

Taverne

Please check the document version of this publication:

- A submitted manuscript is the version of the article upon submission and before peer-review. There can be important differences between the submitted version and the official published version of record.

People interested in the research are advised to contact the author for the final version of the publication, or visit the DOI to the publisher's website.

- The final author version and the galley proof are versions of the publication after peer review.

- The final published version features the final layout of the paper including the volume, issue and page numbers.

Link to publication

\footnotetext{
General rights rights.

- You may freely distribute the URL identifying the publication in the public portal. please follow below link for the End User Agreement:

www.umlib.nl/taverne-license

Take down policy

If you believe that this document breaches copyright please contact us at:

repository@maastrichtuniversity.nl

providing details and we will investigate your claim.
}

Copyright and moral rights for the publications made accessible in the public portal are retained by the authors and/or other copyright owners and it is a condition of accessing publications that users recognise and abide by the legal requirements associated with these

- Users may download and print one copy of any publication from the public portal for the purpose of private study or research.

- You may not further distribute the material or use it for any profit-making activity or commercial gain

If the publication is distributed under the terms of Article $25 \mathrm{fa}$ of the Dutch Copyright Act, indicated by the "Taverne" license above, 


\title{
Retirement and cognitive development in the Netherlands: Are the retired really inactive?
}

\author{
Andries de Grip ${ }^{\mathrm{a}, \mathrm{b}, \mathrm{c}, \mathrm{d}, *}$, Arnaud Dupuy ${ }^{\mathrm{e}, \mathrm{f}, \mathrm{c}}$, Jelle Jolles ${ }^{\mathrm{g}}$, Martin van Boxtel ${ }^{\mathrm{b}}$ \\ ${ }^{\mathrm{a}} \mathrm{ROA}$, The Netherlands \\ ${ }^{\mathrm{b}}$ Maastricht University, The Netherlands \\ 'IZA, Germany \\ ${ }^{\mathrm{d}}$ Netspar, The Netherlands \\ ${ }^{\mathrm{e}}$ CEPS/INSTEAD, Luxembourg \\ ${ }^{\mathrm{f}}$ Maastricht School of Management, The Netherlands \\ ${ }^{\mathrm{g}}$ Free University of Amsterdam, The Netherlands
}

\section{A R T I C L E I N F O}

\section{Article history:}

Received 29 September 2014

Received in revised form 17 August 2015

Accepted 22 August 2015

Available online 7 September 2015

\section{JEL classification:}

$\mathrm{J} 24$

$\mathrm{J} 26$

\section{Keywords:}

Cognitive decline

Labor market activity

Retirement

\begin{abstract}
A B S T R A C T
This paper uses longitudinal data to analyze the relation between retirement and cognitive development in the Netherlands. Controlling for individual fixed effects and lagged cognition, we find that retirees face lower declines in their cognitive flexibility than those who remain employed, which appears to be persistent 6 years after retirement. However, the information processing speed of low-educated retirees declines faster. The magnitude of both changes in cognition is such that retirees appear 5-6 years younger in terms of cognitive flexibility, and older in terms of information processing speed. We show that these relationships between retirement and cognitive development cannot be explained by (1) feeling relieved from routine work, (2) changes in mood, (3) changes in lifestyle, and (4) changes in blood pressure. The decline in information processing speed after retirement particularly holds for the low educated. This could increase the social costs of an aging society.
\end{abstract}

(c) 2015 Elsevier B.V. All rights reserved.

\section{Introduction}

The greying of the post-war baby-boom generation and increased longevity are forcing European countries to postpone the mandatory retirement age to maintain the financial sustainability of the pension systems. This places cognitive function at older ages among the top public health priorities (Mauer, 2010). Skirbekk et al. (2012) show that variation in cognitive functioning of older workers

\footnotetext{
is We acknowledge valuable comments from Eric Bonsang, Bart Golsteyn, Marike Knoef, participants at the International Pension Workshop, Netspar 2012 and EALE 2012 and five anonymous reviewers.

* Corresponding author at: ROA, The Netherlands.

Tel.: +31 433883647; fax: +31 433884914.

E-mail address: a.degrip@maastrichtuniversity.nl (A. de Grip).
}

create large differences in the severity of the ageing problem between countries. Several studies in the economic literature analyze the physical and mental health of early versus later retirement (Dave et al., 2008; Coe and Zamarro, 2011). Furthermore, there is an emerging literature on the effects of labor market inactivity on a person's cognitive abilities. While the psychological literature raises the related question of whether the non-use of cognitive abilities causes cognitive decline (Schaie, 1994; Bosma et al., 2003), it does not relate the use or non-use of cognitive abilities to participation in the labor market. This raises the question of whether we have more cognitive stimuli at work or during retirement, which may mitigate the negative relation between cognitive capacity and age (Salthouse, 2006). Mazzonna and Peracchi (2012) develop a human capital model which explains that those retired lose the incentive to invest in cognitive repair activities. This model, 
however, assumes that individuals only aim to maintain their cognitive abilities for investment purposes. Instead, those who retire from a routine job or retirees who change their lifestyle might have more stimuli to maintain their cognitive abilities when retired. Moreover, Woollett and Maguire (2011), suggest that there might be a trade-off between various dimensions of cognition. This might particularly hold for low skilled who have a limited brain reserve (Staff et al., 2004).

Whereas Coe and Zamarro (2011) do not find any effect, Bonsang et al. (2012) and Rohwedder and Willis (2010) as well as Mazzonna and Peracchi (2012) find that retirement has a negative effect on cognitive functioning. These studies use the same or similar datasets and use country differences in the age pattern of retirement, retirement eligibility or the difference between the actual and legislated ages of eligibility for early and normal retirement to control for unobserved heterogeneity and the endogeneity of retirement decisions. Bingley and Martinello (2013) show that different levels of average schooling across countries drive the negative correlation between retirement and cognitive functioning. Their replication study shows that this explains a large part of the negative retirement effects found in the earlier studies.

Furthermore, most studies focus merely on cognitive ability as measured by a word recall test or a verbal fluency test due to lack of alternative data on other measures of fluid intelligence (Salthouse, 2012). ${ }^{1}$ However, it should be noted that cognition refers to broad aspects of intellectual functioning including cognitive flexibility and information processing speed (Bosma et al., 2003; De Grip et al., 2008; Mauer, 2010).

This paper analyzes the effects of both the transition from work to retirement and being retired on the development of a person's cognitive abilities. ${ }^{2}$ We distinguish between four dimensions of cognition: (1) immediate, (2) delayed verbal memory, (3) cognitive flexibility (Stroop test), and (4) information processing speed and three types of labor market activity namely employed, inactive and retired. Our analyses use longitudinal information on workers' cognitive abilities from the MAastricht Aging Study (MAAS; Jolles et al., 1995). We address the issue of causality using the panel structure of the data. In this data set, a person's cognitive abilities and labor market activity are measured at three points in time, wave 1 in 1993-1995; wave 2 in 1999-2001; wave 3 in 2005-2007. This allows us to measure the impact of changes in labor market activity on a person's cognitive abilities while controlling for individuals' fixed effects and lagged levels of cognition. ${ }^{3}$

\footnotetext{
${ }^{1}$ Mazzonna and Peracchi (2012) also include scores on numeracy and a modified measure of orientation in time in their analyses.

${ }^{2}$ Our data do not allow us to include non-cognitive abilities such as perseverance (see e.g., Heckman, 2006) and creativity (see e.g., Tremblay et al., 2010).

${ }^{3}$ We use the bias-corrected Least Squares Dummy Variable (LSDV) estimator developed by Kiviet (1995) to account for the inherent downward bias in dynamic panel regression with fixed effects. The dynamic fixed-effect model enables us to account for the effect on cognition of unobserved variables that are constant over time conditionally on lagged cognition.
}

The structure of these data allows us to distinguish between those who have been retired for at least 6 years and those who retired in more recent years. This allows us to differentiate between the short-term impact of the transition from work to retirement from the long-term impact of being retired. Furthermore, our data allow us to distinguish between retirement and non-retirement-related inactivity (i.e., unemployment or unpaid housework at an earlier age). This distinction could be important because retirement might be related to different life-style changes than being unemployed. ${ }^{4}$

Our dynamic fixed effects estimates show that those who retire face a significantly smaller decline in cognitive flexibility. This smaller decline appears to be persistent since those who have been retired for six years or more also show a significantly lower decline in cognitive flexibility. The size of the changes in cognitive flexibility related to retirement is considerable and compares to the loss in cognitive flexibility between the ages of 65 and 70-71 years old. However, workers who retire face a significantly higher decline in information processing speed compared to those who remain at work. This reverse change in cognitive development is of similar magnitude to the change in cognitive flexibility related to retirement. Following Coe and Zamarro (2011), we do not find a significant effect of retirement on (delayed) memory as Bonsang et al. (2012), Rohwedder and Willis (2010) and Mazzonna and Peracchi (2012) did. These results show that retirement may have different effects on the various dimensions of a person's cognitive ability.

It is important to note that in as far as our methodology could not remove any dynamic forms of endogeneity, consensus in the current literature is that a negative shock in cognition induces people to retire because they find it more difficult to prolong employment. Hence, those with high cognition remain working, i.e., there is a positive correlation between working and cognition in the absence of any true causal relation. In this case a positive coefficient for work on cognition could simply reflect endogeneity. However, in our paper, we find that retirement is positively related to cognitive flexibility (STROOP). Hence, this outcome cannot be explained by a negative selection into retirement.

We test some hypotheses that may mitigate the relationship between retirement and a person's cognitive development. The first hypothesis focuses on the possibly negative effect of continuous employment in an uninspiring job on a person's cognitive development. From this hypothesis, we derive the expectation that, after a certain age, working has a wearing effect on certain cognitive abilities after someone has been doing the same routines for many years. Therefore those who are low-educated especially may benefit from this relieved effect when they retire. However, as high-skilled workers retire from jobs that

\footnotetext{
${ }^{4}$ Other studies on the relationship between retirement and cognitive functioning consider anyone who is not in the paid labour force as being retired (Coe and Zamarro, 2011), while Bonsang et al. (2012) include all those who are out of the labour market with the intention to of staying out permanently. In these studies, those retired include the disabled.
} 
stimulated their intellectual flexibility (Schooler et al., 1999) retirement might particularly have a negative effect for the high skilled. We test these hypotheses by including an interaction term for the transition from work to retirement with respondents' level of education in the analysis.

Our dynamic fixed effects estimates allow us to control for potential biases due to (i) unobserved heterogeneity that is constant over time and (ii) endogeneity in the retirement decision related to the previous cognition level. However, our estimates are not robust for changes in characteristics that affect both the change in cognition and the retirement decision. We therefore formulate our second and third hypotheses, which further challenge the relation between retirement and cognitive decline by including changes in observed characteristics related to cognition. The second hypothesis builds on the empirical neuropsychological literature, which finds evidence that a person's mood or mental health has a positive effect on cognitive development. Since mood changes are potentially positively related to cognitive development, the positive relation between retirement and cognitive flexibility could be due to a positive effect of retirement on a person's mood relative to continued labor market activity (see Calvo et al., 2007). Conversely, the negative relation between retirement and information processing speed may be explained by a negative effect of retirement on a person's mood. Since our data contains information on individuals' moods at three points in time, we test this hypothesis by including mood changes in the regression of cognitive development on activity status, and check the impact this inclusion has on the relation between retirement on cognitive decline.

The third hypothesis builds on empirical evidence found in the neuropsychological literature on the effect lifestyle can have on cognitive development (see CaleroGarcia and Martinello, 2007; Fratiglioni et al., 2004; Cervilla et al., 2000). Since one expects individuals to change their lifestyle when they retire, the relation between retirement and a person's cognitive development could be due to the effect of retirement on lifestyle. Our data contain detailed information on the physical health of individuals and their drinking habits at the three points of measurement. These indicators for a person's lifestyle can be used to test our hypothesis by including changes in lifestyle characteristics in the regression of activity status on cognitive decline and checking the impact this has on the relation between retirement and cognitive decline.

We found no evidence that changes in lifestyle and mood could explain the positive relation between retirement and a person's cognitive flexibility nor the negative relation between retirement and information processing speed are due to changes in a person's mood or lifestyle upon retirement. However, we find evidence that the negative relation between retirement and a person's information processing speed is only true for low-educated persons.

Our paper contributes to three broader segments of the literature. First, it contributes to the literature on the obsolescence of human capital due to non-use (see Rosen, 1975; Mincer and Ofek, 1982; De Grip et al., 2008) by gaining insight into the differences in the wear and tear effects of cognitive abilities during periods of labor market activity and inactivity. Second, we contribute to the literature (e.g., Costa, 1998) on the social costs and benefits of postponing early and mandatory retirement. Third, we contribute to the literature on the costs and benefits of retirement and other kinds of labor market inactivity at the individual level. Whereas increasing numbers of studies examine the mental health and unhappiness effects of unemployment (e.g., Hamilton et al., 1997; Browning et al., 2006; Tefft, 2010) or retirement (e.g., Lindeboom et al., 2002) only a few, as mentioned above, study the effects on a person's cognitive abilities. These studies, however, do not take into account two major aspects of fluid intelligence: cognitive flexibility and information processing speed (De Grip et al., 2008; Adleman et al., 2002). Furthermore, with the exception of Mazzonna and Peracchi (2012), most studies do not specify a model that distinguishes between workers who recently retired and those who prolong their retirement. Finally, we contribute to this literature by using cognitive tests which are done in a hospital lab setting. This will improve the testing commitment of all participants and might mitigate any possible differences in test effort by employed and retired persons which could occur in an informal setting at home, ${ }^{5}$ and prevent that estimation results are affected by intrahousehold learning which occurs when respondents witness the tests of another household member (Mazzonna and Peracchi, 2012).

The remainder of the paper is organized as follows. Section 2 discusses the data and the measures of cognitive ability, mood and lifestyle that we use in our analyses, including some descriptive statistics. Section 3 outlines our empirical methodology and reports on the estimation results. Section 4 tests the three alternative hypotheses in mitigating the relation between retirement on cognitive decline. Section 5 concludes the paper.

\section{Data}

For this study, we used the data of the MAastricht Aging Study (MAAS) (see Jolles et al., 1995). Participants were recruited from the Registration Network of Family Practices (RNH, Metsemakers et al., 1992), a database of collaborating general family doctors' practices in the region of SouthLimburg, the Netherlands. Exclusion criteria at the baseline were chronic neurological pathology (e.g., evidence of strokes, epilepsy or dementia), mental retardation or chronic psychotropic drug use. Participants were stratified for age (12 age categories), gender, and level of general ability (two levels, based on activities in professional life (Van Berkel and Tax, 1990).

The MAAS data include 1823 individuals who were between 24 and 81 years old at the baseline measurement in 1993-1995, say, time T. After six years, 1388 persons (76.1\%) were retested with the same test battery (i.e., in the period 1999-2001), at $T+6$, while after 12 years (i.e., in the period 2005-2007), at $T+12,1208$ persons (66.3\%) were again retested. The probability of dropping out is not

\footnotetext{
5 Duckworth et al. (2011) show that under low-stakes research conditions test motivation could affect test results as some individuals try harder than others.
} 
related to age, gender, education, labor market activity or cognitive measures (in levels and change), except for information processing speed, for which there is some evidence that those who dropped out between wave 2 and 3 had experienced a lower decline in that measure between the first two measurements. ${ }^{6}$ These data comprise a three-period unbalanced panel of about 1360 individuals for which we could estimate regressions including lagged variables. On average, individuals were observed 2.7 times.

These data enable us to distinguish between three different labor market statuses: employed, retired, and (other) inactive. The "retired" category encompasses early retirement (those younger than 65 years who stated they are retired) and retirement defined as people aged 65 (i.e., the mandatory retirement age) or older who do not have paid work. Those who are neither employed nor retired are classified as inactive. ${ }^{7}$

As indicated by the transition matrices between $t$ and $t+6$, with $t=T, T+6$, reported in Table F1 in the Appendix, a non-negligible number of persons changed their employment status in the two periods we distinguished. In both periods about $20 \%$ change their employment status. This means that we have sufficient observations off the diagonal to distinguish between, for instance, persons inactive at both $t$ and $t+6$ from those inactive at $t$ but employed at $t+6$. The remainder of the paper distinguishes between six groups: those inactive at both $t$ and $t+6$ (group II), those inactive at $t$ and employed at $t+6$ (group $I E$ ), those retired at both $t$ and $t+6$ (group $R R$ ), those employed at $t$ and inactive at $t+6$ (group $E I$ ), those employed at $t$ and retired at $t+6$ (group $E R$ ), and the reference group $(E E)$, consisting of those employed both at $t$ and $t+6$.

\subsection{Cognitive abilities}

In the three test periods, $T, T+6$ and $T+12$, respondents underwent the same set of standard neuropsychological tests to assess the following cognitive domains:

- Memory, as in immediate recall (Word Learning Task or WLT test).

- Memory, as in delayed recall (WLT test).

- Cognitive flexibility (Stroop test).

- Information processing speed (Letter Digit Substitution Test or LDST).

The WLT evaluates the ability to acquire and retain new verbal information (Van der Elst et al., 2005). In each of three trials, a set of 15 frequently used monosyllabic words were presented in a fixed order at a rate of one every 2 seconds. These tests enable us to measure two aspects of a person's cognitive abilities: their immediate recall abilities and their delayed recall abilities. After every trial,

\footnotetext{
${ }^{6}$ These results are derived from a (probit) regression of the attrition status (dummy equals one if a participant dropped out of the study) on labor market activity, levels and changes in our four measures of cognition and age and education. Detailed results are available from the authors upon request.

${ }^{7}$ When those who are inactive reach the age of 65 we consider these individuals to remain inactive as there is not any change in circumstances.
}

the participant had to reproduce the memorized words (immediate recall test). The total number of correctly reproduced words in three trials was recorded. ${ }^{8}$ Twenty minutes after the last trial, the participant was again asked to reproduce the set of words (delayed recall test) and the number of correctly reproduced words was recorded.

Selective attention and susceptibility to perceptual interference was measured by the Stroop Color and Word Test (Stroop, 1935; Van der Elst et al., 2006b) which indicates a person's cognitive flexibility. The test involves naming as quickly as possible the colors of the printing ink of 100 names of colors that do not match the color of the ink with which they are printed. The number of seconds to complete the task is recorded. ${ }^{9}$ Performance in this test is determined largely by the time needed to discard irrelevant but very salient information (verbal) in favor of a less obvious aspect (the printing ink color). It should be noted that a higher score (i.e., more seconds) on this test indicates lower cognitive ability.

Finally, we used the LDST, a paper-and-pencil task in which a person is asked to copy as accurately and as quickly as possible the numbers in a series of boxes that are indexed by a unique letter. The letters refer to nine letternumber combinations displayed in a table at the top of the test sheet. The number of correctly copied numbers after 90 seconds is used as the measure of interest (Van der Elst et al., 2006a). In neuropsychological assessment, this test is often used to obtain a general measure of information processing speed (Lezak, 2004).

It is important to note that since employment status (retirement) is correlated with age, one needs to carefully isolate changes in cognition due to age from changes due to other causes (e.g., changes in employment status). As Figs. 1 and 2 in the Appendix suggest, the age-profiles of cognition and cognitive decline can be accurately approximated by low-order polynomials, for instance the quadratic form.

Table F2 in the Appendix shows the average mean levels and standard deviations of the variables for the three groups on which our analyses focus. The table shows that those who remained employed between $t$ and $t+6$ had higher cognitive abilities than those who remained retired. Moreover, those who retired (i.e., changed from being employed to being retired) between $t$ and $t+6$ also had lower cognitive abilities than those who remained employed. However, these differences are largely due to the large difference in average age between the two groups.

In addition, Table F3 shows the average changes in the variables used over the two 6-year periods for the three groups of interest. The table shows that none of the means of the changes are statistically significant. When comparing the means of a variable across groups it should be noted

\footnotetext{
${ }^{8}$ Interviewees have no strict time restrictions. When they cannot recall more words they are asked whether they think they know more words. If not, then the trial stops. This was always within $60 \mathrm{~s}$.

${ }^{9}$ If the person gives the wrong answer he or she should give a second reply, i.e., for each item the Stroop test waits till the person gives the correct answer. Wrong answers therefore lengthen the time it takes to pass all items.
} 
WLT

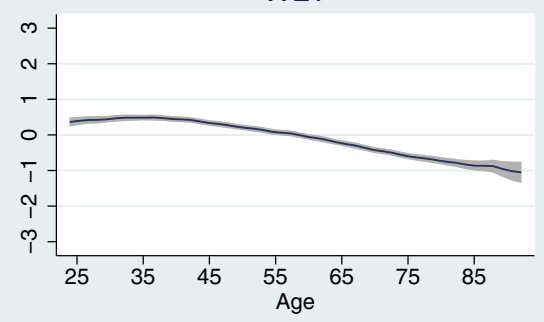

Stroop

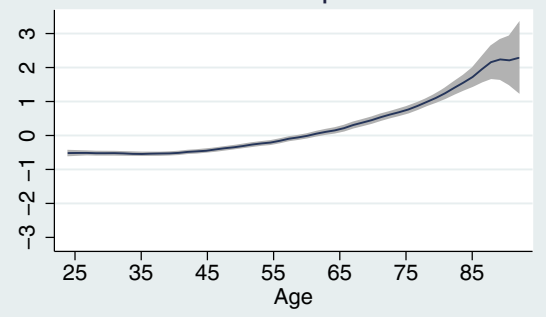

WLT delay

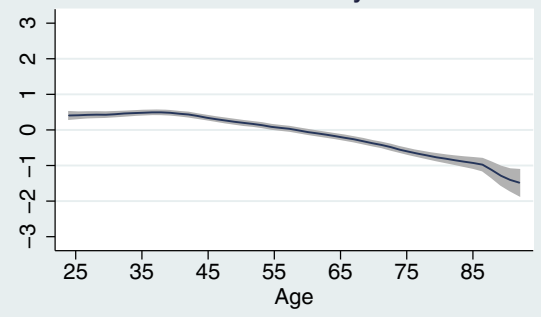

LDST

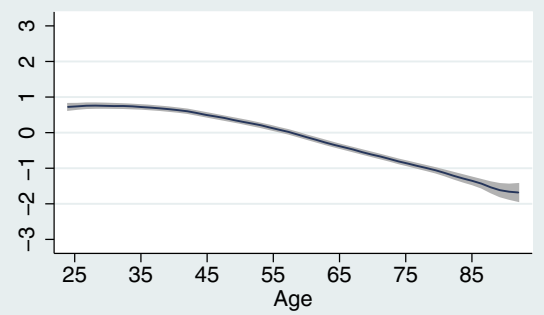

Fig. 1. Cognition scores and age. Local polynomial smoothing and 95\% confidence interval of the $z$-score, expressed in standard deviation units, by age.

that the various groups differ along many important dimensions such as age and education that are not accounted for in this table.

\subsection{Mood}

Our test of alternative explanations for the relation between cognitive decline and retirement when measuring cognition by information processing or cognitive flexibility uses the data available on the respondents' mood. To measure mood, we use the respondents' responses to moodrelated questions that ask the respondents to express the extent to which they agree with 16 statements related to their mood or mental health ('depression') (cf. Wallace and Herzog, 1995). The following is a subset of four of these statements.

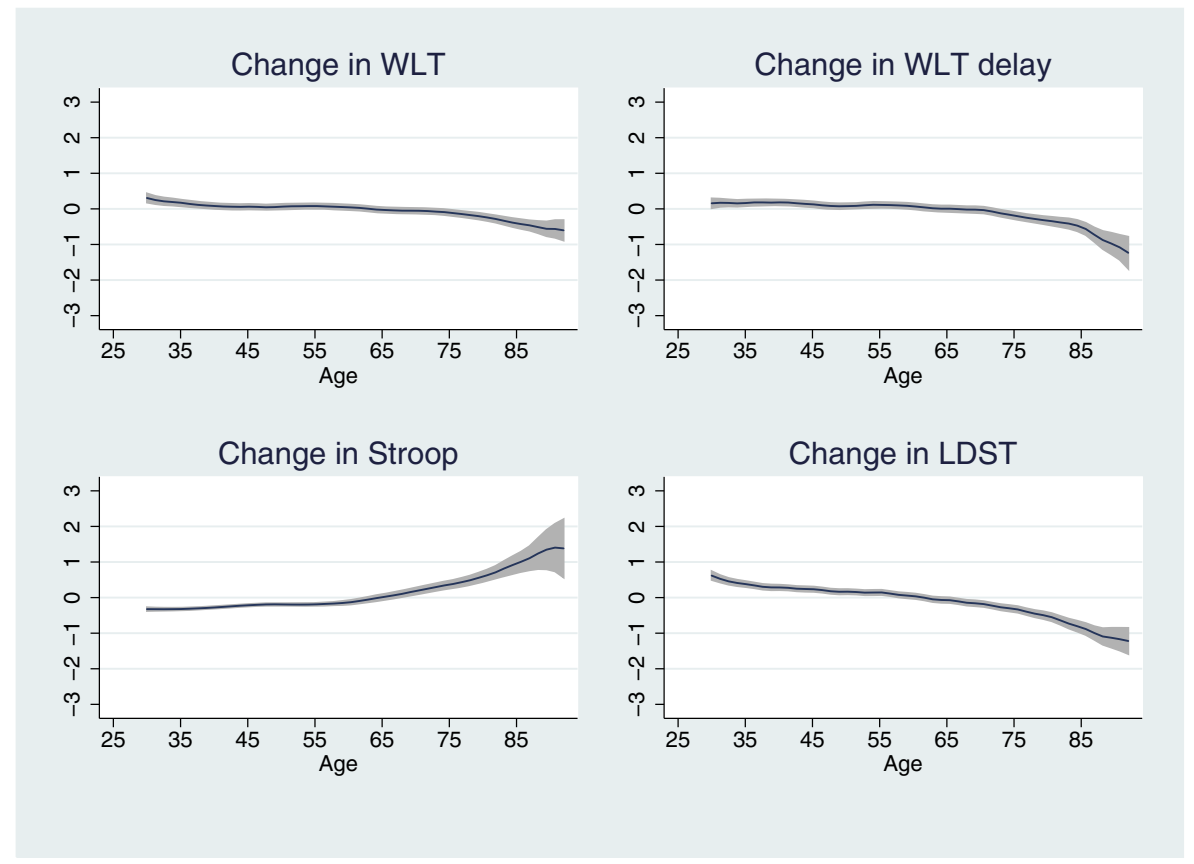

Fig. 2. Change in cognitive scores and age. Local polynomial smoothing and $95 \%$ confidence interval of the $z$-score, expressed in standard deviation units, by age. 
On a scale from 1 (absolutely not) to 5 (totally), to what extent does the following apply to you?

- I blame myself for everything happening to me.

- I feel lonely.

- I am at the far end of my rope.

- I am irritable.

Principal component analysis on the 16 statements reveals that the answer to the third statement above, "I am at the far end of my rope," correlates very strongly, at about 0.84 , with the first two principal components that together explain about $50 \%$ of the total variance. Since missing values are relatively frequent and scattered across statements, we limited the number of missing values by using the answer to this particular statement as a proxy for mood, rather than the sum of the answers to all 16 statements. ${ }^{10}$ We construct our measure of mood by subtracting the answer to the statement from zero such that a higher score indicates a better mood. Table F2 shows the average mood changes over the two 6 -year periods for the 3 groups of main interest. The table shows that none of the means of the changes are statistically significant.

\subsection{Lifestyle}

To test our third hypothesis on the effect of differences in life style on cognitive development, we use data available on the physical health and drinking behavior of the respondents. Since we are interested in physical health changes related to life styles, changes in Body Mass Index $\left(\Delta B M I_{t+6}\right)$ and diastolic blood pressure, ${ }^{11}\left(\Delta B P_{t+6}\right)$, seem to be the most appropriate variables. Moreover, we use the available data on changes in drinking behavior as proxied by the average number of glasses of alcohol per day $\left(\Delta D D\right.$ rink $\left._{t+6}\right)$. However, of the 1360 respondents selected, we only obtained information on alcohol use for about 990 persons in the three waves. Table F3 shows the average changes in the three lifestyle indicators over the two 6-year periods for the three groups of main interest. The table shows that none of the means of the changes are statistically significant.

\section{Empirical methodology and results}

\subsection{Main model}

This paper analyzes the impact of labor market status on cognition. The model we estimate is:

$$
\begin{aligned}
\operatorname{Cog}_{i t+6}= & X_{i t+6}^{\prime} \beta+Z_{i}^{\prime} \omega+\alpha \operatorname{Cog}_{i t}+\delta_{E R} E R_{i t}+\delta_{R R} R R_{i t} \\
& +\delta_{I I} I I_{i t}+\delta_{I E} I E_{i t}+\delta_{E I} E I_{i t}+\tau_{t}+\varepsilon_{i t+6}
\end{aligned}
$$

\footnotetext{
${ }^{10}$ Alternatively we also have also used the first principal component of the statements on mood. This analysis gives similar results for the main variables of interest as in Table 4.

11 The dataset also includes a measure of auditive functioning, but this measure (in levels or changes) is not correlated with labor market activity or our measures of cognition. We have also tested alternative specifications such as systolic BP as well as dummies on changes in BMI passing obesity thresholds 30 and 35 .
}

where $X_{i t}^{\prime}$ contains covariates that vary over time, age, and age squared, ${ }^{12} Z_{i}$ contains covariates that are constant over time such as gender, eight educational dummies and eight occupational dummies. $E R_{i t}$ takes the value one if person $i$ was employed at $t$ and retired at $t+6$ and zero otherwise, $R R_{i t}$ takes the value one if person $i$ was retired at $t$ and retired at $t+6$ and zero otherwise, $I I_{i t}$ takes the value one if person $i$ was inactive at $t$ and $t+6$ and zero otherwise, $I E_{t i}$ takes the value one if person $i$ was inactive at $t$ and employed at $t+6$ and zero otherwise and $E I_{i t}$ takes the value one if person $i$ was employed at $t$ and inactive at $t+6$ and zero otherwise. $\tau_{t}$ a period-specific fixed effect. Furthermore, we relate cognition at $t+6$ to a person's level of cognition at $t$. This enables us to take into account the fact that the absolute loss of cognition may be higher for those with higher levels of cognition at the beginning of the period.

We begin the analysis by estimating the model depicted in Eq. (3.1) ignoring the panel structure of the data and applying OLS to the pooled cross-section for our four measures of cognition, respectively the WLT, delayed WLT, Stroop and LDST separately. As noted, a higher score indicates higher cognitive abilities for all tests but the Stroop, where a high score (i.e., more seconds) indicates lower cognitive abilities.

Table 1 shows that those who were retired at both $t$ and $t+6$ show a significantly higher cognitive flexibility compared to people who were employed at both $t$ and $t+6$. For those who were inactive at both $t$ and $t+6$ we find a similar (although smaller) relationship. However, we do not find a similar significant effect for those who retired between $t$ and $t+6$. Furthermore, our estimation results show that, for all four measures, cognitive abilities at $t+6$ are positive and significantly related to initial cognition. These results should however be interpreted with care since the OLS method does not allow one to control for individual fixed effects which might bias the results.

Next we estimate the model using fixed effects techniques. The effect of variables contained in $Z_{i}$, fixed over time, are now captured as part of the individual fixed effects $\mu_{i}$ :

$$
\begin{aligned}
\operatorname{Cog}_{i t+6}= & X_{i t+6}^{\prime} \beta+\alpha \operatorname{Cog}_{i t}+\delta_{E R} E R_{i t}+\delta_{R R} R R_{i t}+\delta_{I I} I_{i t} \\
& +\delta_{I E} I E_{i t}+\delta_{E I} E I_{i t}+\tau_{t}+\mu_{i}+\varepsilon_{i t+6}
\end{aligned}
$$

As is well known in the literature (Nickell, 1981), the slope coefficients in this model are downward biased when using Least Dummy Variable Estimator (LSDV). To correct for this bias, we apply Kiviet's (1995) bias-corrected LSDV estimator (LSDVC), and in particular use the Stata routine xtlsdvc developed by Bruno (2005). ${ }^{13}$

It is important to note that our specification in Eq. (3.2) is dynamic. The identifying assumption of our fixed effects model requires that the effect of unobserved variables on cognition is constant over time conditional on lagged cognition. This identifying assumption is weaker than that required in a static fixed effects model because we take

\footnotetext{
12 As suggested by Figs. 1 and 2, the quadratic form is sufficient to pick up the age profile in cognitive decline. Higher orders are rarely significant.

${ }^{13}$ Standard deviations are derived using the bootstrapping procedure of Bruno (2005) in order to account for the unbalanced nature of our panel.
} 
Table 1

Impact of labor market status on cognitive ability: OLS regressions.

\begin{tabular}{|c|c|c|c|c|}
\hline & WLT & WLT del & Stroop & LDST \\
\hline Employed to Employed & Ref. & Ref. & Ref. & Ref. \\
\hline Retired to Retired & $\begin{array}{l}0.16 \\
(0.36)\end{array}$ & $\begin{array}{l}0.34^{*} \\
(0.18)\end{array}$ & $\begin{array}{l}-5.29^{* * * *} \\
(1.93)\end{array}$ & $\begin{array}{l}0.67 \\
(0.44)\end{array}$ \\
\hline Employed to Retired & $\begin{array}{l}0.11 \\
(0.46)\end{array}$ & $\begin{array}{l}0.12 \\
(0.24)\end{array}$ & $\begin{array}{l}-3.71 \\
(2.48)\end{array}$ & $\begin{array}{l}-0.77 \\
(0.56)\end{array}$ \\
\hline Inactive to Inactive & $\begin{array}{l}0.02 \\
(0.27)\end{array}$ & $\begin{array}{l}0.02 \\
(0.14)\end{array}$ & $\begin{array}{l}-2.93^{* * *} \\
(1.45)\end{array}$ & $\begin{array}{l}0.01 \\
(0.33)\end{array}$ \\
\hline Inactive to Employed & $\begin{array}{l}-0.07 \\
(0.41)\end{array}$ & $\begin{array}{l}0.20 \\
(0.21)\end{array}$ & $\begin{array}{l}0.51 \\
(2.19)\end{array}$ & $\begin{array}{l}0.13 \\
(0.501\end{array}$ \\
\hline Employed to Inactive & $\begin{array}{l}0.07 \\
(0.39)\end{array}$ & $\begin{array}{l}0.04 \\
(0.20)\end{array}$ & $\begin{array}{l}-3.05 \\
(2.05)\end{array}$ & $\begin{array}{l}-0.11 \\
(0.47)\end{array}$ \\
\hline Lagged cognition & $\begin{array}{l}0.55^{* * * *} \\
(0.02)\end{array}$ & $\begin{array}{l}0.60^{* * * *} \\
(0.02)\end{array}$ & $\begin{array}{l}0.90^{* * * *} \\
(0.03)\end{array}$ & $\begin{array}{l}0.83^{* * * * *} \\
(0.01)\end{array}$ \\
\hline Age & $\begin{array}{l}0.11^{* *} \\
(0.05)\end{array}$ & $\begin{array}{l}0.13^{* * * *} \\
(0.03)\end{array}$ & $\begin{array}{l}-1.66^{* * * *} \\
(0.28)\end{array}$ & $\begin{array}{l}0.28^{* * * *} \\
(0.06)\end{array}$ \\
\hline Age square $(/ 100)$ & $\begin{array}{l}-0.18^{* * *} \\
(0.04)\end{array}$ & $\begin{array}{l}-0.16 \\
(0.02)\end{array}$ & $\begin{array}{l}2.03^{* * * *} \\
(0.24)\end{array}$ & $\begin{array}{l}-0.40^{* * *} \\
(0.05)\end{array}$ \\
\hline Female & $\begin{array}{l}1.02^{* * *} \\
(0.20)\end{array}$ & $\begin{array}{l}0.54^{* * * *} \\
(0.10)\end{array}$ & $\begin{array}{l}-2.17^{* *} \\
(1.05)\end{array}$ & $\begin{array}{l}0.70^{* * *} \\
(0.24)\end{array}$ \\
\hline Dummy wave 3-2 & $\begin{array}{l}1.04^{* * * *} \\
(0.20)\end{array}$ & $\begin{array}{l}0.50^{* * * *} \\
(0.10)\end{array}$ & $\begin{array}{l}-1.01 \\
(0.98)\end{array}$ & $\begin{array}{l}4.88^{* * * *} \\
(0.23)\end{array}$ \\
\hline Constant & $\begin{array}{l}9.58^{* * * *} \\
(1.59)\end{array}$ & $\begin{array}{l}1.22 \\
(0.80)\end{array}$ & $\begin{array}{l}42.17^{* * * *} \\
(8.54)\end{array}$ & $\begin{array}{l}0.634 \\
(1.20)\end{array}$ \\
\hline $\begin{array}{l}\text { Education } \\
\text { dummies }\end{array}$ & Yes & Yes & Yes & Yes \\
\hline Occupation dummies & Yes & Yes & Yes & Yes \\
\hline Marital status dummies & Yes & Yes & Yes & Yes \\
\hline Observations & 2444 & 2442 & 2413 & 2443 \\
\hline$R$ squared & 0.282 & 0.242 & 0.148 & 0.354 \\
\hline
\end{tabular}

Standard errors in parentheses.

(a) In the Standard Classification of Occupations of Statistics Netherlands occupation is defined on a scale from 1 lower level to 7 higher level.

* $p<0.10$.

** $p<0.05$.

*** $p<0.01$.

into account the effect on cognition of unobserved variables that are constant over time at given levels of past cognition. ${ }^{14}$ In other words, if individuals decide to retire between $t$ and $t+6$ based on their level of cognition at $t$, then our estimates are consistent while the static fixed-effects estimates would be inconsistent. Only when the decision to retire between $t$ and $t+6$ is related to the cognition at $t+6$ conditional on the cognition at $t$, would our estimates be biased. ${ }^{15}$ Section 4 of this paper provides extensions that attempt to control further for the endogeneity of retirement decision of the latter type by including variables that affect cognition and change over time.

The results are reported in Table 2 . With respect to information processing (LDST), cognitive decline is larger and significant for those who retired between $t$ and $t+6$ compared to those who continued working,

\footnotetext{
${ }^{14}$ Robustness analyses however show that excluding the lagged cognition does not affect our main results significantly.

15 As we only observe people every six years we cannot take account of sudden drops in cognition in the years in between that might cause retirement decisions later in the 6 -year period. However, our finding that those who retire face less decline with respect to their cognitive flexibility is at odds with this potential bias of our results.
}

Table 2

Impact of labor market status on cognitive ability: fixed-effects regressions.

\begin{tabular}{|c|c|c|c|c|}
\hline & WLT & WLT-del & Stroop & LDST \\
\hline \multirow{3}{*}{$\begin{array}{l}\text { Employed to Employed } \\
\text { Retired to Retired }\end{array}$} & Ref. & Ref. & Ref. & Ref. \\
\hline & 0.18 & 0.22 & $-8.90^{*}$ & -1.31 \\
\hline & $(0.69)$ & $(0.41)$ & $(4.79)$ & $(1.31)$ \\
\hline \multirow[t]{2}{*}{ Employed to Retired } & 0.02 & 0.31 & $-5.66^{*}$ & $-1.88^{* * * *}$ \\
\hline & $(0.60)$ & $(0.25)$ & $(3.06)$ & $(0.72)$ \\
\hline \multirow[t]{2}{*}{ Inactive to Inactive } & 0.37 & 0.35 & -2.88 & -0.64 \\
\hline & $(0.61)$ & $(0.31)$ & $(3.02)$ & $(0.85)$ \\
\hline \multirow[t]{2}{*}{ Inactive to Employed } & 0.21 & 0.41 & -2.21 & 0.17 \\
\hline & $(0.55)$ & $(0.30)$ & $(3.4)$ & $(0.85)$ \\
\hline \multirow[t]{2}{*}{ Employed to Inactive } & -0.24 & 0.29 & -3.92 & -0.18 \\
\hline & $(0.52)$ & $(0.23)$ & $(2.79)$ & $(0.70)$ \\
\hline \multirow[t]{2}{*}{ Lagged cognition } & $-0.09^{*}$ & 0.04 & 0.24 & $0.29^{* * *}$ \\
\hline & $(0.05)$ & $(0.05)$ & $(0.22)$ & $(0.12)$ \\
\hline \multirow[t]{2}{*}{ Age } & 0.07 & $0.41^{* *}$ & $-6.39^{* * *}$ & $0.87^{* *}$ \\
\hline & $(0.29)$ & $(0.17)$ & $(1.53)$ & $(0.37)$ \\
\hline \multirow[t]{2}{*}{ Age square (/100) } & $-0.25^{* * *}$ & $-0.34^{* * *}$ & $4.88^{* * * *}$ & $-1.04^{* * *}$ \\
\hline & $(0.09)$ & $(0.05)$ & $(0.68)$ & $(0.15)$ \\
\hline \multirow[t]{2}{*}{ Dummy wave 3-2 } & -1.22 & 0.56 & -12.52 & 2.84 \\
\hline & $(1.83)$ & $(0.99)$ & $(9.13)$ & $(2.02)$ \\
\hline Observations & 2444 & 2442 & 2413 & 2443 \\
\hline No. of individuals & 1359 & 1360 & 1341 & 1358 \\
\hline \multicolumn{5}{|c|}{ Standard errors in parentheses. } \\
\hline \multirow{2}{*}{\multicolumn{5}{|c|}{$\begin{array}{l}* p<0.10 \\
* * \quad p<0.05\end{array}$}} \\
\hline & & & & \\
\hline \multicolumn{5}{|l|}{$*^{* * *} p<0.01$} \\
\hline
\end{tabular}

while with respect to cognitive flexibility (Stroop test) the cognitive decline is still lower and significant. This finding shows that the relation between retirement and cognitive development has a different direction for different dimensions of cognition. The magnitude of both changes in cognition is considerable, resembling the difference in cognition between the age of 65 and 70 years old.

Table F4 in the Appendix shows the estimation results of a static fixed-effects model. The table shows that we get similar results with respect to memory, but also for our most remarkable results: the positive relation between retirement and cognitive flexibility. The negative relation between retirement and information processing speed is no longer significant. However, it should be noted that the static fixed-effects model does not include the lagged cognition which controls for potential biases due to endogeneity in the retirement decision related to the previous cognition level.

Furthermore, we have experimented with various age specifications such as selecting only respondents aged 50 and above at baseline or adding a cubic term. In all these specifications we found estimates for $E R$ and $R R$ of a similar magnitude as those presented in this paper. The estimates are still significant for the cubic specification but when we select only those aged 50 or more at baseline measurement all coefficients for the various labor market status groups become insignificant although we find similar coefficients as in our estimates with the full sample. It should however be noted that we analyse cognitive development during a period of 12 years. When 
we only include those who were 50 or older at baseline measurement we have a very small number of employed workers who are employed in the third wave of the panel as the average retirement age in the Netherlands was below 61 in these years. Finally, we also ran models separately for men and women and found no significant differences. ${ }^{16}$

\subsection{Measurement errors and the testing effect}

As is well known in the psychological literature, cognitive tests suffer from a testing effect; that is, at constant cognitive ability, people will perform better at a test they have already done in the past (see e.g., Karpicke and Roediger, 2008). The testing effect could be seen as a specific change in measurement errors from wave to wave. Including the Dummy for wave 3-2 into the regression takes into account the general impact of the testing effect, whereas lagged cognition might measure a testing effect which is related to individuals' level of cognition (see Table 2).

One may still argue, however, that measurement errors are systematic and drive the strong negative effect of retirement on cognitive decline. Suppose indeed that cognition is measured with errors and write $\operatorname{Cog}=\mathrm{Co}$ $g^{*}+$ err where $\operatorname{Cog}$ is measured cognition, $\operatorname{Cog}^{*}$ is real cognition, and the err are measurement errors. Suppose further that the errors of measurement systematically differ across employment groups and especially between retired people and workers. A possible reason for this could be that retired people are more motivated to perform well in the test, are less stressed, or have more time to prepare, such that they have better test results than those with the same cognitive abilities but who are still employed. In this case, it is conceivable that for retired persons measured cognition is equal to true cognition $\operatorname{Cog}=\operatorname{Cog}^{*}$, while for employed persons measured cognition is below true cognition, $\operatorname{Cog}<\operatorname{Cog}^{*}$ or $\operatorname{err}<0$. Hence, we would find a larger cognition for retired persons relative to persons that remain employed even if true cognition is the same for both groups. Although theoretically possible, the change in the "motivation" of retired people relative to the employed that is required to fit with the coefficients shown in Table 2 is implausible. Retired people, for instance, need to increase their motivation for the Stroop test compared to employed persons to increase their cognition by six to seven points compared to those employed. As mentioned above, the magnitudes of our estimates correspond to the loss of cognition a person experiences between the ages of 65 and 70 years. This casts serious doubts on the plausibility of measurement errors as the driving force behind the lower decline in cognitive flexibility we found for retired persons. In addition, a higher test effort of the retired is not in line with the greater decline in their information processing speed.

\footnotetext{
${ }^{16}$ The results of these estimates are available from the authors upon request.
}

Table 3

Fixed-effects regressions: heterogeneous effects of retirement by level of education (high-educated versus low-educated).

\begin{tabular}{|c|c|c|c|c|}
\hline & WLT & WLT-del & Stroop & LDST \\
\hline Employed to Employed & Ref. & Ref. & Ref. & Ref. \\
\hline \multirow[t]{2}{*}{ Retired to Retired } & 0.18 & 0.14 & $-8.70^{*}$ & -1.58 \\
\hline & $(0.67)$ & $(0.41)$ & $(4.82)$ & $(1.31)$ \\
\hline \multirow[t]{2}{*}{ Employed to Retired } & 0.04 & -0.14 & -4.63 & $-3.36^{* * *}$ \\
\hline & $(0.78)$ & $(0.34)$ & (3.89) & $(0.98)$ \\
\hline \multirow{2}{*}{$\begin{array}{l}\text { Employed to Retired } \\
\text { for high educated }\end{array}$} & -0.02 & $0.84^{*}$ & -1.86 & $2.79^{* *}$ \\
\hline & $(0.97)$ & $(0.47)$ & $(4.95)$ & $(1.41)$ \\
\hline \multirow[t]{2}{*}{ Inactive to Inactive } & 0.37 & 0.32 & -2.81 & -0.73 \\
\hline & $(0.61)$ & $(0.31)$ & $(3.08)$ & $(0.85)$ \\
\hline \multirow[t]{2}{*}{ Inactive to Employed } & 0.21 & 0.40 & -2.18 & 0.12 \\
\hline & $(0.55)$ & $(0.30)$ & $(3.43)$ & $(0.86)$ \\
\hline \multirow[t]{2}{*}{ Employed to Inactive } & -0.24 & 0.27 & -3.89 & -0.22 \\
\hline & $(0.53)$ & $(0.23)$ & $(2.79)$ & $(0.70)$ \\
\hline \multirow[t]{2}{*}{ Lagged cognition } & $-0.09^{*}$ & 0.04 & 0.24 & $0.30^{* *}$ \\
\hline & $(0.05)$ & $(0.05)$ & $(0.22)$ & $(0.12)$ \\
\hline \multirow[t]{2}{*}{ Age } & 0.07 & $0.41^{* * *}$ & $-6.38^{* * *}$ & $0.83^{* * *}$ \\
\hline & $(0.29)$ & $(0.17)$ & $(1.54)$ & $(0.37)$ \\
\hline \multirow[t]{2}{*}{ Age square $(/ 100)$} & $-0.25^{* * *}$ & $-0.34^{* * * *}$ & $4.87^{* * *}$ & $-1.03^{* * *}$ \\
\hline & $(0.09)$ & $(0.05)$ & $(0.68)$ & $(0.15)$ \\
\hline \multirow[t]{2}{*}{ Dummy wave 3-2 } & -1.22 & 0.53 & -12.50 & 2.72 \\
\hline & $(1.83)$ & $(0.99)$ & $(9.13)$ & $(2.03)$ \\
\hline Observations & 2444 & 2442 & 2413 & 2443 \\
\hline No. of individuals & 1359 & 1360 & 1341 & 1358 \\
\hline \multicolumn{5}{|c|}{ Standard errors in parentheses. } \\
\hline \multicolumn{5}{|c|}{${ }^{*} p<0.10$} \\
\hline \multicolumn{5}{|l|}{$* * \quad p<0.05$} \\
\hline \multicolumn{5}{|l|}{${ }^{* * *} p<0.01$} \\
\hline
\end{tabular}

\section{Tests of alternative hypotheses}

\subsection{Cognitive declines among the low educated}

The lower cognitive decline of retired persons could be due to the fact that working after a certain age has a wearing effect on cognitive ability. This "relieved effect" can especially occur when low-educated workers retire from a job in which that repeated the same routines for years. Low-educated workers who retire might therefore have a higher level of cognition than those who remain employed. Conversely, particularly retirees who are lower educated might develop a very inactive lifestyle. However, Schooler et al. (1999) find that having complex work that requires "thought and independent judgment" improves intellectual flexibility. Therefore retirement might particularly have a negative effect on those who retire from a more complex job. To test these competing hypotheses, we check whether the effect of retirement on cognitive decline is linked to workers' level of education. For this purpose, we augment our regression with the interaction of retirement $E R$ with workers' level of education, focusing on the dichotomy between high educated (higher secondary education, higher vocational education and university) and low-educated persons. ${ }^{17}$ However, we find evidence

\footnotetext{
17 The estimation results, presented in Table 3 show that the decline in cognitive flexibility is unrelated to their level of education of those who retire from employment.
} 
that in contrast to the expectation we derived from Schooler et al. (1999) higher-educated retirees face a significantly lower decline in their information processing speed (as measured by the LDST) when retired than when still employed. This suggests that it is the low educated who suffer from a decline in information processing speed upon retirement. Using the estimates of Table 3 , we find that a 65-year-old low-educated retired person has the information processing cognition of a 71-year-old worker.

\subsection{Do mood and life-style changes explain the lower cognitive decline of retirees?}

Since mood and life-style have been recognized as major determinants of cognitive decline, retirement may cause a lower decline in cognitive flexibility when retirees improve their mood compared to persons who remain employed, or when their lifestyle is more favorable to cognitive development than that of those who continue working. Conversely, the higher decline in information processing speed for those who retire from work might be explained by a worse mood or lifestyle for retirees. We test for the effect of mood and lifestyle by adding mood changes as well as lifestyle changes to Eq. (3.2).

We estimate Eq. (4.1), which augments Eq. (3.2) with changes in $W_{i t+6}$ between $t$ and $t+6$ where $W$ is the vector containing mood and our measures of lifestyle (BMI, blood pressure and alcohol consumption): ${ }^{18}$

$$
\begin{aligned}
\operatorname{Cog}_{i t+6}= & X_{i t+6}^{\prime} \beta+\alpha \operatorname{Cog}_{i t}+\delta_{E R} E R_{i t}+\delta_{R R} R R_{i t}+\delta_{I I} I I_{i t} \\
& +\delta_{I E} I E_{i t}+\delta_{E I} E I_{i t}+\Delta W_{i t+6}^{\prime} \gamma+\tau_{t}+\mu_{i} \\
& +\varepsilon_{i t+6}
\end{aligned}
$$

If the variables in $W$ are responsible for the relation between retirement and cognitive decline, with $\Delta W_{i t+6}$ in the regression, the coefficients for mood or lifestyle, $\gamma$, should be significant and, at the same time, the coefficients for $\delta_{R R}$ and $\delta_{E R}$ should drop and become insignificant.

\subsubsection{Results}

Table 4 reports the estimation results when including the variables on individuals' mood and lifestyle. We use three indicators to proxy for respondents' "revealed" lifestyles. The first two indicators reflect changes in lifestyle concerning a person's physical health, namely, changes in (1) BMI, $\left(\Delta B M I_{t+6}\right)$, and (2) diastolic blood pressure, $\left(\Delta B P_{t+6}\right) .^{19}$ The last life-style variable reflects respondents' drinking behavior, namely the change in (3)

\footnotetext{
18 To overcome a drop in sample size due to partial non-response to several of these variables, we include, for each of these variables, a dummy variable taking for value 1 if the individual did not answer the associated question and 0 otherwise, and impute a random value to the variable itself where it is missing. This allows us to perform the regression on the same sample as when these variables are not included. The estimation results are similar to those of separate regressions on the various mood and lifestyle variables.

${ }^{19}$ Whereas Tzourio et al. (1999) find that high blood pressure is associated with cognitive decline, Sturman et al. (2008) show that adjusted for age, sex, race, and education, higher BMI is associated with less cognitive decline.
}

Table 4

Impact of labor market status on cognitive ability: fixed-effects

\begin{tabular}{|c|c|c|c|c|}
\hline & WLT & WLT-del & Stroop & LDST \\
\hline Employed to Employed & Ref. & Ref. & Ref. & Ref. \\
\hline Retired to Retired & $\begin{array}{l}0.26 \\
(0.68)\end{array}$ & $\begin{array}{l}0.28 \\
(0.42)\end{array}$ & $\begin{array}{l}-8.22^{*} \\
(4.8)\end{array}$ & $\begin{array}{l}-1.81 \\
(1.32)\end{array}$ \\
\hline Employed to Retired & $\begin{array}{l}0.03 \\
(0.61)\end{array}$ & $\begin{array}{l}0.31 \\
(0.25)\end{array}$ & $\begin{array}{l}-6.10^{* *} \\
(3.01)\end{array}$ & $\begin{array}{l}-2.10^{* * *} \\
(0.72)\end{array}$ \\
\hline Inactive to Inactive & $\begin{array}{l}0.49 \\
(0.62)\end{array}$ & $\begin{array}{l}0.37 \\
(0.32)\end{array}$ & $\begin{array}{l}-2.13 \\
(3.05)\end{array}$ & $\begin{array}{l}-0.83 \\
(0.86)\end{array}$ \\
\hline Inactive to Active & $\begin{array}{l}0.27 \\
(0.55)\end{array}$ & $\begin{array}{l}0.38 \\
(0.29)\end{array}$ & $\begin{array}{l}-1.46 \\
(3.40)\end{array}$ & $\begin{array}{l}0.03 \\
(0.84)\end{array}$ \\
\hline Active to Inactive & $\begin{array}{l}-0.26 \\
(0.53)\end{array}$ & $\begin{array}{l}0.24 \\
(0.23)\end{array}$ & $\begin{array}{l}-3.84 \\
(2.78)\end{array}$ & $\begin{array}{l}-0.24 \\
(0.70)\end{array}$ \\
\hline Lagged cognition & $\begin{array}{l}-0.09^{*} \\
(0.05)\end{array}$ & $\begin{array}{l}0.03 \\
(0.05)\end{array}$ & $\begin{array}{l}0.22 \\
(0.22)\end{array}$ & $\begin{array}{l}0.28^{* * *} \\
(0.12)\end{array}$ \\
\hline Age & $\begin{array}{l}0.032 \\
(0.29)\end{array}$ & $\begin{array}{l}0.42^{* * *} \\
(0.17)\end{array}$ & $\begin{array}{l}-6.85^{* * *} \\
(1.59)\end{array}$ & $\begin{array}{l}0.86^{* *} \\
(0.38)\end{array}$ \\
\hline Age square $(/ 100)$ & $\begin{array}{l}-0.29^{* * *} \\
(0.10)\end{array}$ & $\begin{array}{l}-0.37^{* * *} \\
(0.05)\end{array}$ & $\begin{array}{l}4.52^{* * *} \\
(0.64)\end{array}$ & $\begin{array}{l}-0.93^{* * *} \\
(0.15)\end{array}$ \\
\hline $\begin{array}{l}\text { Change in drinks } \\
\text { per day }\end{array}$ & $\begin{array}{l}-0.04 \\
(0.06)\end{array}$ & $\begin{array}{l}0.02 \\
(0.03)\end{array}$ & $\begin{array}{l}0.26 \\
(0.39)\end{array}$ & $\begin{array}{l}0.02 \\
(0.09)\end{array}$ \\
\hline Change in mood & $\begin{array}{l}0.11 \\
(0.10)\end{array}$ & $\begin{array}{l}0.079^{* *} \\
(0.04)\end{array}$ & $\begin{array}{l}-0.06 \\
(0.57)\end{array}$ & $\begin{array}{l}-0.00 \\
(0.11)\end{array}$ \\
\hline Change in BMI & $\begin{array}{l}0.03 \\
(0.04)\end{array}$ & $\begin{array}{l}0.04^{*} \\
(0.02)\end{array}$ & $\begin{array}{l}0.35 \\
(0.29)\end{array}$ & $\begin{array}{r}-0.09 \\
(0.06)\end{array}$ \\
\hline $\begin{array}{c}\text { Change in blood } \\
\text { pressure }\end{array}$ & $\begin{array}{l}0.01 \\
(0.01)\end{array}$ & $\begin{array}{l}-0.00 \\
(0.00)\end{array}$ & $\begin{array}{l}0.09^{* *} \\
(0.04)\end{array}$ & $\begin{array}{l}0.01 \\
(0.01)\end{array}$ \\
\hline Dummy wave 3-2 & $\begin{array}{l}-1.68 \\
(1.81)\end{array}$ & $\begin{array}{l}0.47 \\
(1.02)\end{array}$ & $\begin{array}{l}-17.58^{*} \\
(9.24)\end{array}$ & $\begin{array}{l}3.28 \\
(2.02)\end{array}$ \\
\hline Observations & 2444 & 2442 & 2413 & 2443 \\
\hline No. of individuals & 1359 & 1360 & 1341 & 1358 \\
\hline
\end{tabular}
regressions controlled for changes in Mood, BMI, Alcohol consumption and blood pressure.

Standard errors in parentheses

To overcome a drop in sample size due to partial non-response to several of these variables, we included for each of these variables, a dummy variable taking for value 1 if the individual did not answer the associated question and 0 otherwise, and impute a random value to the variable itself where it is missing (see Footnote 18).

$* p<0.10$

** $p<0.05$.

*** $p<0.01$

the average number of glasses of alcohol per day, $\left(\Delta\right.$ GDrink $\left._{t+6}\right){ }^{20}$ The results reported in Table 4 show that changes in mood are only positively related to delayed memory changes. However, in this regression the coefficients for those who retired between $t$ and $t+6$ as well as those who were retired at both $t$ and $t+6$ remain insignificant. Changes in BMI and daily alcohol consumption are not related to any of the measures of cognitive development except for a weakly significant relationship between BMI and delayed memory changes. We conclude that with respect to cognitive flexibility and information processing speed the relationships between cognitive development and retirement cannot be attributed to

\footnotetext{
20 Zins et al. (2011) show that around retirement, the estimated prevalence of heavy drinking increased in both sexes. Meta-analyses of Peters et al. (2008) suggest that small amounts of alcohol may be protective against cognitive decline.
} 
changes in mood, BMI or alcohol consumption. A similar conclusion can be derived for changes in blood pressure, except for cognitive flexibility, as indicated in Table 4. Indeed, the results show that those who experience an increase in blood pressure also have to cope with a significantly stronger decline in their cognitive flexibility (i.e., a higher score on the Stroop test). Nevertheless, this does not alter the relation between the decline in cognitive flexibility and retirement; that is, the coefficients are of similar magnitude as in the previous specifications and the coefficient of those who retire between $t$ and $t+6$ becomes even significant at the $5 \%$ level, as shown in Table $4 .^{21}$

\section{Conclusion and implications}

This paper uses longitudinal test data to analyze the relation between retirement and a person's cognitive development with respect to memory, cognitive flexibility, and information processing speed. Our data allow us to distinguish between the effects of the transition from work to retirement on a person's cognitive development and the persistence of these effects after being retired for a longer period. Controlling for individual fixed effects and lagged cognition, we find that those who retire from work face greater declines with respect to information processing speed than those who remain employed. However, those who retire face less decline with respect to their cognitive flexibility. This relation appears to be persistent after being retired for at least six years. The coefficients we find are comparable to the effect of a 5- to 6-year age difference. The alternative hypotheses we test show that both relationships cannot be explained by (1) a relieved effect after being employed in routine jobs, or a negative effect for high-educated workers who leave a job that fostered their cognitive abilities, (2) changes in mood, or (3) changes in lifestyle upon retirement. Controlling for changes in blood pressure, which are negatively related to cognitive flexibility, we find the lower decline in cognitive flexibility for the retirees still holds. However, since our proxies for a person's lifestyle only pick up the effects of lifestyle related to physical health, we can only conclude that differences in lifestyle that may affect cognitive decline are not related to physical health or drinking habits. The same holds for mental health, in-sofar as this is measured by our mood indicator. Our data do not allow us to analyze whether the lower decline in cognitive flexibility of retirees is related to being involved in more intellectual activities (Erickson et al., 1986), social relationships (Cohen, 2004), or a more varied lifestyle (volunteer activities, traveling, etc.) after retirement (Siegrist et al., 2004).

The contrasting results we find for information processing and cognitive flexibility seem to suggest a

\footnotetext{
21 We have also tested alternative specifications such as systolic BP as well as dummies on changes in BMI passing obesity thresholds 30 and 35 in which we found very similar results to those reported in the paper. Non-parametric fit of the relations between our four measures of cognition and BP or BMI in our data also shows no indications of nonlinearity or discontinuity.
}

trade-off between different aspects of cognition (although the latter is only weakly significant in the baseline estimation): Participating in activities that develop one aspect of cognition (cognitive flexibility) might reduce the development of other aspects (information processing). This resembles the findings of Woollett and Maguire (2011), who show that experienced qualified London taxi drivers display a greater memory for spatial knowledge but lesser memory for the delayed recall of complex figures compared to less experienced or retired taxi drivers or control participants. Our findings suggest that this trade-off might particularly hold for low-educated retirees.

Our estimation results do not support the "findings of Bonsang et al. (2012), Rohwedder and Willis (2010) and Mazzonna and Peracchi (2012) with respect to persons' recall abilities. However, with respect to these memory abilities our findings resemble those of Coe and Zamarro (2011). The positive relation we find between retirement and a person's cognitive flexibility shows that retirement does not necessarily refer to the non-use of a person's cognitive abilities. Retirees may, for instance, enrich their lives through voluntary activities, travel, and other challenging activities that broaden their scope compared to the narrower range of activities at work before retirement. From this perspective, it is understandable that this finding particularly holds for a person's cognitive flexibility. When persons retire, they have to learn new routines and may get involved in a much broader range of new activities than they were involved in at the end of their working careers. It is interesting to see that this does not hold for those who become inactive at a younger age because of unemployment or other causes of labour market inactivity.

As mentioned in the beginning of the paper, our findings might suffer from an endogeneity problem as people self-select into retirement. We apply dynamic fixed effect models which cannot rule out any dynamic forms of endogeneity. We should therefore interpret our results with caution. As most studies indicate a negative selection into retirement, the greater decline of information processing speed we find for low-educated workers who retire from work might overestimate the causal effect of retirement. However, the positive relation we find between retirement and a person's cognitive flexibility cannot be explained from a negative selection into retirement.

Obviously, our findings may have important policy implications. To cope with the increasing costs of an aging population, in many industrialized countries public policy aims to postpone the mandatory age of retirement. Our results suggest that this postponement of retirement has a positive effect on the information processing speed of the elderly but accelerates the decline of their cognitive flexibility, which may increase both the social and financial costs of an aging population. Since the decline in information processing speed after retirement is especially true for the low-educated, activating such persons after retirement could lower the social costs of an aging society. 


\section{Appendix}

Table F1

Employment status transition matrix between $T$ and $T+6$ (1365 obs) and $T+6$ and $T+12$ (1185 obs).

\begin{tabular}{|c|c|c|c|c|c|}
\hline & & \multicolumn{4}{|c|}{ Activity at $T+6$} \\
\hline & & Inactive & Retired & Employed & Total \\
\hline \multirow[t]{4}{*}{ Activity at $T$} & Inactive & 22.2 & 0 & 4.8 & 27.0 \\
\hline & Retired & 0 & 19.6 & 0 & 19.6 \\
\hline & Employed & 5.3 & 3.5 & 45.6 & 54.4 \\
\hline & Total & 27.5 & 23.1 & 50.4 & 100 \\
\hline
\end{tabular}

\begin{tabular}{|c|c|c|c|c|c|}
\hline & & \multicolumn{4}{|c|}{ Activity at $T+12$} \\
\hline & & Inactive & Retired & Employed & Total \\
\hline \multirow[t]{4}{*}{ Activity at $T+6$} & Inactive & 17.9 & 0 & 8.5 & 26.4 \\
\hline & Retired & 0 & 23.7 & 0 & 23.7 \\
\hline & Employed & 5.0 & 7.0 & 37.9 & 49.9 \\
\hline & Total & 22.9 & 30.7 & 46.4 & 100 \\
\hline
\end{tabular}

Note that because of mandatory retirement at age 65 in the Netherlands and relatively large pension benefits for those who retire at an earlier age, transitions from retirement to employment or inactivity are zero.

Table F2

Summary statistics: Average mean levels and standard deviations for the 3 groups of interest.

\begin{tabular}{|c|c|c|c|c|c|c|c|c|c|}
\hline & $\begin{array}{l}N \\
\text { Retired }\end{array}$ & $\begin{array}{l}\text { Mean } \\
\text { to }\end{array}$ & $\begin{array}{l}\text { SD } \\
\text { Retired }\end{array}$ & $\begin{array}{l}N \\
\text { Employed }\end{array}$ & $\begin{array}{l}\text { Mean } \\
\text { to }\end{array}$ & $\begin{array}{l}\text { SD } \\
\text { Retired }\end{array}$ & $\begin{array}{l}N \\
\text { Employed }\end{array}$ & $\begin{array}{l}\text { Mean } \\
\text { to }\end{array}$ & $\begin{array}{l}\text { SD } \\
\text { Employed }\end{array}$ \\
\hline WLT & 319 & 22.64 & 5.86 & 111 & 25.50 & 5.68 & 1069 & 28.45 & 5.85 \\
\hline WLTdel & 319 & 8.86 & 3.49 & 110 & 10.02 & 3.05 & 1070 & 11.70 & 2.83 \\
\hline Stroop & 310 & 121.50 & 47.95 & 106 & 97.52 & 22.71 & 1066 & 84.99 & 30.06 \\
\hline LDST & 317 & 40.50 & 11.35 & 111 & 47.23 & 11.99 & 1071 & 56.65 & 10.81 \\
\hline Age & 318 & 75.32 & 6.51 & 111 & 65.72 & 7.29 & 1072 & 47.76 & 11.40 \\
\hline Female & 318 & 0.30 & 0.46 & 111 & 0.29 & 0.46 & 1072 & 0.39 & 0.49 \\
\hline Education & 318 & 3.21 & 1.78 & 111 & 3.91 & 1.98 & 1072 & 4.38 & 1.75 \\
\hline Occupation & 319 & 3.71 & 1.90 & 111 & 4.26 & 1.72 & 1072 & 4.10 & 1.68 \\
\hline Mood & 302 & -1.48 & 0.90 & 111 & -1.34 & 0.69 & 983 & -1.38 & 0.72 \\
\hline BMI & 308 & 27.09 & 4.02 & 110 & 27.54 & 4.22 & 1054 & 26.78 & 4.21 \\
\hline Blood presure & 262 & 104.12 & 16.19 & 100 & 103.20 & 14.79 & 1033 & 98.57 & 13.79 \\
\hline Drinks/day & 279 & 1.74 & 1.72 & 106 & 2.15 & 1.86 & 942 & 2.61 & 2.32 \\
\hline
\end{tabular}

Note that for all cognitive tests but Stroop a higher score indicates a higher cognitive ability. A higher score on Stroop indicates a lower cognitive ability.

(a) Education is classified on a scale from 1 is elementary to 8 is scientific.

(b) Occupation is defined on a scale from 1 lower level to 7 higher level.

Note that when occupation is not known, it is coded 0 . The share of unknowns is roughly constant across activity.

Table F3

Summary statistics (continue): change in variables over time for the 3 groups of interest.

\begin{tabular}{|c|c|c|c|c|c|c|c|c|c|}
\hline & $\begin{array}{l}N \\
\text { Retired }\end{array}$ & $\begin{array}{l}\text { Mean } \\
\text { to }\end{array}$ & $\begin{array}{l}\text { SD } \\
\text { Retired }\end{array}$ & $\begin{array}{l}N \\
\text { Employed }\end{array}$ & $\begin{array}{l}\text { Mean } \\
\text { to }\end{array}$ & $\begin{array}{l}\text { SD } \\
\text { Retired }\end{array}$ & $\begin{array}{l}N \\
\text { Employed }\end{array}$ & $\begin{array}{l}\text { Mean } \\
\text { to }\end{array}$ & $\begin{array}{l}\text { SD } \\
\text { Employed }\end{array}$ \\
\hline Delta.WLT & 319 & 0.3 & 4.9 & 110 & 0.5 & 5.1 & 1068 & 1.6 & 5.1 \\
\hline Delta.WLTdel & 319 & -0.2 & 2.6 & 110 & 0.2 & 2.6 & 1066 & 0.5 & 2.3 \\
\hline Delta.Stroop & 310 & 15.0 & 39.9 & 106 & 6.0 & 13.5 & 1064 & 1.1 & 20.4 \\
\hline Delta.LDST & 315 & -3.3 & 7.8 & 111 & -3.8 & 7.5 & 1070 & 0.3 & 5.9 \\
\hline Delta.Mood & 296 & -0.1 & 1.2 & 110 & 0.0 & 0.9 & 971 & -0.1 & 0.9 \\
\hline Delta.BMI & 304 & -0.4 & 1.8 & 109 & -0.3 & 1.5 & 1047 & 0.5 & 2.3 \\
\hline Delta.Blood presure & 252 & -1.2 & 19.1 & 100 & 3.0 & 20.1 & 1022 & 2.4 & 13.4 \\
\hline Delta.Drinks/day & 272 & -0.5 & 1.5 & 97 & -0.1 & 1.5 & 914 & -0.2 & 2.1 \\
\hline
\end{tabular}


Table F4

Impact of labor market status on cognitive ability: (static) fixed-effects regressions.

\begin{tabular}{lllll}
\hline & WLT & WLT-del & Stroop & LDST \\
\hline Employed to Employed & Ref. & Ref. & Ref. & Ref. \\
Retired to Retired & -0.29 & 0.25 & $-3.74^{*}$ & 0.54 \\
& $(0.41)$ & $(0.21)$ & $(2.16)$ & $(0.48)$ \\
Employed to Retired & 0.38 & $0.54^{* *}$ & $-6.66^{* * *}$ & -0.34 \\
& $(0.44)$ & $(0.23)$ & $(2.37)$ & $(0.52)$ \\
Inactive to Inactive & -0.14 & 0.06 & $-2.93^{* *}$ & 0.45 \\
& $(0.29)$ & $(0.15)$ & $(1.55)$ & $(0.34)$ \\
Inactive to Employed & -0.15 & 0.12 & -0.03 & 0.18 \\
& $(0.37)$ & $(0.19)$ & $(1.94)$ & $(0.43)$ \\
Employed to Inactive & -0.11 & 0.10 & -3.15 & 0.34 \\
& $(0.38)$ & $(0.20)$ & $(2.02)$ & $(0.45)$ \\
Age & $0.41^{* * *}$ & $0.24^{* * *}$ & $-3.62^{* * *}$ & $0.82^{* * *}$ \\
& $(0.05)$ & $(0.02)$ & $(0.25)$ & $(0.06)$ \\
Age square (/100) & $-0.21^{* * * *}$ & $-0.19 *$ & $4.20^{* * *}$ & $-0.93^{* * * *}$ \\
& $(0.05)$ & $(0.02)$ & $(0.25)$ & $(0.06)$ \\
Dummy wave 3-2 & $-1.33^{* * * *}$ & $-0.46^{* * *}$ & -0.58 & -2.61 \\
& $(0.13)$ & $(0.07)$ & $(0.71)$ & $(0.16)$ \\
Constant & $9.15^{* * * *}$ & $3.24^{* * *}$ & $159.89^{* * *}$ & $34.07^{* * *}$ \\
& $(1.23)$ & $(0.63)$ & $(6.48)$ & $(1.44)$ \\
Observations & 4327 & 4323 & 4288 & 4326 \\
No. of individuals & 1798 & 1798 & 1791 & 1798 \\
\hline
\end{tabular}

Standard errors in parentheses.

${ }^{*} p<0.10$.

** $p<0.05$

*** $p<0.01$.

\section{References}

Adleman, N., Menon, V., Blasey, C., White, C., Warsofsky, I., Glover, G. Reiss, A., 2002. A developmental fMRI study of the Stroop Color-Word Task. Neuroimage 16, 61-75.

Bingley, P., Martinello, A., 2013. Mental retirement and schooling. Eur. Econ. Rev. 63 (4), 292-298.

Bonsang, Eric, S.A., Perelman, S., 2012. Does retirement affect cognitive performance? J. Health Econ. 31, 490-501.

Bosma, H., Van Boxtel, M., Ponds, R., Houx, P., Burdorf, A., Jolles, J., 2003. Mental work demands protect against cognitive impairment: MAAS Prospective Cohort Study. Exp. Aging Res. 29, 33-45.

Browning, M., Moller Dano, A., Heinesen, E., 2006. Job displacement and stress-related health outcomes. Health Econ. 15 (10), 1061-1075.

Bruno, G.S., 2005. Approximating the bias of the LSDV estimator for dynamic unbalanced panel data models. Econ. Lett. 87 (3) 361-366.

Calero-Garcia, M., Munoz-Manz, L., 2007. Influence of level of activity on cognitive performance and cognitive plasticity in elderly persons. Arch. Gerontol. Geriatr. 45 (3), 307-318.

Calvo, E., Haverstick, K., Sass, S.A., 2007. What Makes Retirees Happier: A Gradual or 'Cold Turkey' Retirement? Working Papers, WP 2007-18. Center for Retirement Research at Boston College.

Cervilla, J., Prince, M., Joels, S., Lovestone, S., Mann, A., 2000. Long-term predictors of cognitive outcome in a cohort of older people with hypertension. Br. J. Psychiatry 177, 66-71.

Coe, N.B., Zamarro, G., 2011. Retirement effects on health in Europe. J. Health Econ. 30 (1), 77-86.

Cohen, S., 2004. Social relationship and health. Am. Psychol. 59 (8), $676-$ 684.

Costa, D.L., 1998. The evolution of retirement: summary of a research project. Am. Econ. Rev. 88 (2), 232-236.

Dave, D., Rashad, I., Spasojevic, J., 2008. The effects of retirement on physical and mental health outcomes. South. Econ. J. 75, 497-523.

De Grip, A., Bosma, H., Willems, D., Van Boxtel, M., 2008. Job-worker mismatch and cognitive decline. Oxf. Econ. Pap. 60, 237-253.

Duckworth, A., Quinn, P., Lynamc, D., Loeber, R., Stouthamer-Loeber, M., 2011. Role of test motivation in intelligence testing. Proc. Natl. Acad. Sci. U. S. A. 108, 7717-7720.

Erickson, E.H., Erickson, J.M., Kivnick, H.Q., 1986. Vital Involvement in Old Age. Norton, New York, NY.
Fratiglioni, L., Paillard-Borg, S., Winblad, B., 2004. An active and socially integrated lifestyle in late life might protect against dementia. Lancet Neurol. 3, 343-353.

Hamilton, V., Merrigan, P., Dufresne, E., 1997. Down and out: estimating the relationship between mental health and unemployment. Health Econ. 6, 397-406

Heckman, J., 2006. The economics, technology and neuroscience of human capability formation. Proc. Natl. Acad. Sci. U. S. A. 104, 1325013255.

Jolles, J., Houx, P., Van Boxtel, M., Ponds, R.W.H.M., 1995. Maastricht Aging Study: Determinants of Cognitive Aging. Neuropsych Publishers.

Karpicke, J.D., Roediger, H.L., 2008. The critical importance of retrieval for learning. Science 319, 966-968.

Kiviet, J.F., 1995. On bias, inconsistency, and efficiency of various estimators in dynamic panel data models. J. Econom. 68 (1), 53-78.

Lezak, M.D., 2004. Neuropsychological Assessment. Oxford University Press, New York.

Lindeboom, M., Portrait, F., Van Den Berg, G., 2002. An econometric analysis of the mental-health effects of major events in the life of older individuals. Health Econ. 11 (6), 505-520.

Mauer, J., 2010. Height, education and later-life cognition in Latin America and the Caribbean. Econ. Hum. Biol. 8 (2), 168-176.

Mazzonna, F., Peracchi, F., 2012. Ageing, cognitive abilities and retirement. Eur. Econ. Rev. 56, 691-710.

Metsemakers, J.F.M., Hoppener, P., Knottnerus, J., Kocken, R.J.J., Limonard, C.B.G., 1992. Computerized health information in the netherlands: a registration network of family practices. Br. J. Gen. Pract. 42, 102-106.

Mincer, J., ofek, H., 1982. Interrupted work careers: depreciation and restoration of human capital. J. Hum. Resour. 17, 3-24.

Nickell, S., 1981. Biases in dynamic models with fixed effects. Econometrica 49 (6), 1417-1426.

Peters, R., Peters, J., Warner, J., Beckett, N., Bulpitt, C., 2008. Alcohol, dementia and cognitive decline in the elderly: a systematic review. Age Ageing 37 (5), 505-512.

Rohwedder, S., Willis, R.J., 2010. Mental retirement. J. Econ. Perspect. 24 119-138.

Rosen, S., 1975. Measuring the obsolescence of knowledge. In: Juster, F.T (Ed.), Education, Income and Human Behavior. Carnegie Foundation for the Advancement of Teaching and National Bureau of Economic Research, New York, pp. 199-232.

Salthouse, T., 2006. Mental exercise and mental aging: evaluating the validity of the "use it or lose it" hypothesis. Perspect. Psychol. Sci. 1 68-87.

Salthouse, T., 2012. Consequences of age-related cognitive declines. Annu. Rev. Psychol. 63, 201-226.

Schaie, K., 1994. The course of adult intellectual development. Am. Psychol. 49, 304-313.

Schooler, C., Mulatu, M.S., Oates, G., 1999. The continuing effects of substantively complex work on the intellectual functioning of older workers. Psychol. Aging 14, 483-506.

Siegrist, J., Von Dem Knesebeck, O., Pollack, C.E., 2004. Social productivity and well-being of older people: a sociological exploration. Soc. Theory Health 2 (1), 1-17.

Skirbekk, V., Loichinger, E., Weber, D., 2012. Variation in cognitive functioning as a refined approach to comparing aging across countries. Proc. Natl. Acad. Sci. U. S. A. 109, 770-774.

Staff, R.T., Murray, A.D., Deary, I.J., Whalley, L.J., 2004. What provides cerebral reserve? Brain 127, 1191-1199.

Stroop, J.R., 1935. Studies of interference in serial verbal reactions. J. Exp. Psychol. 18, 643-662.

Sturman, M.T., Mendes de Leon, C., Bienias, J., Morris, M., Wilson, R., Evans, D., 2008. Body mass index and cognitive decline in a biracial community population. Neurology 70 (5), 360-367.

Tefft, N., 2010. Mental health and employment: the SAD story. Econ. Hum. Biol. 10 (3), 242-255.

Tremblay, C., Grosskopf, S., Yang, K., 2010. Brainstorm: occupational choice, bipolar illness and creativity. Econ. Hum. Biol. 8 (2), 233 241.

Tzourio, C., Dufouil, C., Ducimetière, P., Alpérovitch, A., 1999. Cognitive decline in individuals with high blood pressure: a longitudinal study in the elderly. Neurology 53 (9), 1948-1952.

Van Berkel, A.B., Tax, B., 1990. Naar Een Standaardoperationalisatie Van Sociaal-Economische Status Voor Epidemiologisch En Sociaal-Medisch Onderzoek (Towards a Standard Operationalization of Socio-Economical Status for Epidemiological and Socio-Economical Research). Ministerie van Welzijn, Volksgezondheid en Cultuur, Den Haag.

Van der Elst, W., Van Boxtel, M.P., Van Breukelen, G.J., Jolles, J., 2006a. The Stroop color-word test: influence of age, sex, and education; and normative data for a large sample across the adult age range. Assessment $13,62-79$. 
Van der Elst, W., Van Boxtel, M.P.J., Van Breukelen, G.J.P., Jolles, J., 2005. Rey's verbal learning test: normative data for 1855 healthy participants aged 24-81 years and the influence of age, sex, education, and mode of presentation. J. Int. Neuropsychol. Soc. 11, 290-302.

Van der Elst, W., Van Boxtel, M.P.J., Van Breukelen, G.J.P., Jolles, J., 2006b.

The letter digit substitution test: normative data for 1858 healthy participants aged 24-81 from the Maastricht Aging Study (MAAS). Influence of age, education, and sex. J. Clin. Exp. Neuropsychol. 28, 998-1009.
Wallace, R.B., Herzog, A.R., 1995. Overview of the health measures in the health and retirement study. J. Hum. Resour. 30, S84-S107.

Woollett, K., Maguire, E.A., 2011. Acquiring the knowledge of London's layout drives structural brain changes. Curr. Biol. 21, 2109-2114.

Zins, M., Guéguen, A., Kivimaki, M., Singh-Manoux, A., Leclerc, A., Vahtera, J., Westerlund, H., Ferrie, J., Goldberg, M., 2011. Effect of retirement on alcohol consumption: longitudinal evidence from the French Gazel Cohort Study. PLoS ONE 6 (10) . 